\title{
CUSTOMER SATISFACTION IN MOBILE PAYMENT SYSTEM : FINDING FROM INDONESIA
}

\author{
Rian Hermawan ${ }^{1}$ \\ ${ }^{1}$ Faculty of Economics, Universitas Negeri Jakarta \\ Jakarta, Indonesia \\ rianhermawannn@gmail.com \\ Mohamad Rizan ${ }^{2}$ \\ ${ }^{2}$ Faculty of Economics, Universitas Negeri Jakarta \\ Jakarta, Indonesia \\ mohamadrizan72@unj.ac.id \\ Agung Wahyu Handaru ${ }^{3}$ \\ ${ }^{3}$ Faculty of Economics, Universitas Negeri Jakarta \\ Jakarta, Indonesia \\ ahandaru@unj.ac.id
}

\begin{abstract}
This research was conducted to produce a customer loyalty model in the mobile payment business in Indonesia. Mobile payments are a vast need felt by consumers, especially in urban areas with good quality internet networks. Even though it is online, it still requires good customer service and can provide user satisfaction with this application. In this mobile payment business competition, the Link Aja company tries to compete with several platforms with several weaknesses in its business strategy. To achieve the research objectives, a sample selection of 200 users of the Link Aja mobile platform who live in Jakarta was selected. Non-probability sampling techniques are used to facilitate the collection of primary data needed to analyze the structural equation models used to test the hypothesis. The results of hypothesis testing reveal that service quality, promotion, and customer satisfaction have a positive impact on the level of customer loyalty of the Link Aja platform. Besides, customer satisfaction itself is influenced by the quality of service and promotions carried out by the Link Aja
\end{abstract}


platform. The recommendation for the Link Aja platform is to immediately improve the service quality and create more promotion to get more customer loyalty. Keywords: Service Quality, Promotion, Customer Satisfaction, Customer Loyalty.

\section{INTRODUCTION}

The development of the digital world is increasingly making it easier for users. Everything is made easier thanks to advanced digital features. Money, which was initially in physical form, is now connected in the grip of a smartphone. From a smartphone, payment transactions can now be made using the mobile payment feature. Mobile payments are now included in the dominating ranks of non-cash transactions. The rapid movement of mobile payments from time to time has made fintech makers compete in creating mobile payments that excel in various features. In the future, so that this innovation can be used in quantity, it can be more effective than physical money. Link wrote a state-owned company that pioneered mobile payment technology since 2007. Optimal service has been provided by Link Aja. Promotions carried out by Link Aja have also been carried out in various media. At the end of 2018, the link only ranks third, even though the link or t-cash is the first mobile payment in Indonesia. The high opportunities for mobile payments in the future are, of course, used by fintech owners to be used and relied on by their users. Profits in the future will be what mobile payment applicators want. To achieve sustainable profitability, loyalty from customers is what the company wants. To form continuous and optimal dedication, it is necessary to provide satisfaction to customers. Customer satisfaction can be constructed from many variables. In this case, customer satisfaction appears to be formed from the excellent quality of service and the effectiveness of the promotions that have been carried out. This study aimed to determine the effect of service quality and advertising on customer loyalty through customer satisfaction at Link Aja customers as the object of research. This research begins with systematic research starting from the introduction, literature review and hypothesis formulation, research methodology, and discussion results. 


\section{LITERATURE REVIEW}

\section{Service Quality and Its Effect on Customer Satisfaction}

According to Tjiptono (2012), service quality is a measure of how good the level of service provided is following customer expectations. According to Arief (2007), service quality or service is the level of perfection expected in delivering exemplary service when compared to customer expectations in fulfilling customer desires. According to Parasuraman (1988), service quality compares services felt to be the same or exceed the expected service quality. The quality of service can be enriched and satisfactory. Based on this definition, it can be concluded that service quality is a measure of how good the level of service provided by service providers is with the level of perfection expected by customers. Zheithalm et al in Ariani (2009) states that there are five main elements known as SERQUAL which consist of physical evidence, reliability, responsiveness, assurance, and empathy.

\section{The Effect of Promotion on Customer Satisfaction}

According to Philip Kotler (2001), promotion is an activity carried out by companies to communicate the benefits of their products/services and to convince consumers to buy. According to Tjiptono (2012), promotion is a marketing activity that seeks to spread information, influence / persuade and remind the target market of the company and its products/services so that they are willing to accept, buy and be loyal to the products offered by the company concerned. According to Sistaningrum (2002), promotion is an effort or company activity in influencing actual and potential consumers. Based on this definition, it can be concluded that promotion is an activity carried out by a company to influence customers by communicating benefits. According to Philip Kottler (2012), there are five promotion elements: advertising, sales promotion, public relations, direct selling, and direct marketing.

\section{Customer Satisfaction as An Important Concept in Marketing Management}

According to Kotler (2001), satisfaction is defined as feeling happy or disappointed by someone that arises from comparing the perceived performance/reality experienced against the expectations or expectations. According to Usmara (2003), satisfaction compares performance expectations before buying and perceptions of performance received by consumers after buying or using services. According to Husain Umar (2003), 
customer satisfaction is an after-purchase evaluation. Based on this definition, it can be concluded that customer loyalty is the difference between expectations and the results of perceived performance, in the form of pleasure or disappointment that is felt after buying or using a service. Customer satisfaction is the basis for the realization of loyal or loyal customers. According to Dutka in Bahar \& Sjaharuddin (2015), there are three dimensions in measuring customer satisfaction, namely attribute related to the product, attributes related to service, and attribute related to purchase.

\section{Customer Loyalty in the Strategy Model}

According to Budiarta and Fachira (2017), Customer Loyalty is service/product users who value relationships with the company adequately and make the company a service provider for the products/services they choose. According to Lovelock and Wirtz (2011), Customer Loyalty is customer behavior shown by being willing to purchase/reuse products/services in the long term and are eager to recommend products/services to others. Based on this definition, it can be concluded that customer loyalty is the commitment of the customer to persist in making the selected purchase/use, appreciates the relationship between the customer and the company adequately, and is willing to recommend the product/service to others. The elements of customer loyalty, according to Kottler and Keller (2006), are repeat, retention, and referral.

\section{Research Framework}

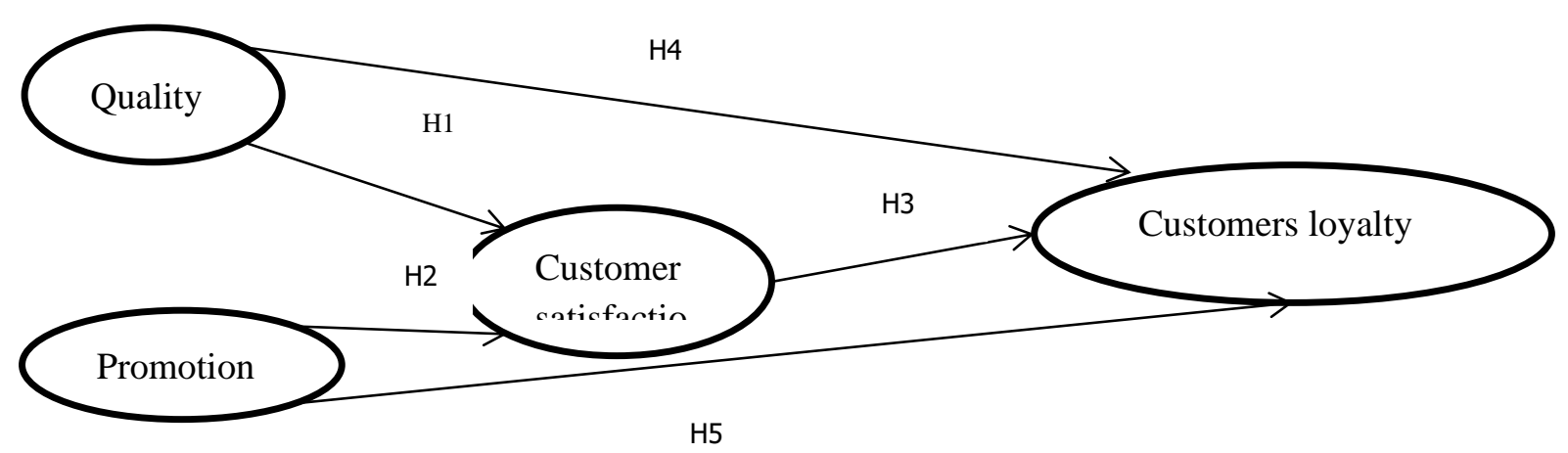

Figure 1. Research Model 
While the hypotheses compiled in this study are following the above framework of thought:

Hypothesis 1 There is an influence between service quality variables on customer satisfaction variables.

Hypothesis 2 There is an influence between promotional variables on customer satisfaction variables.

Hypothesis 3 There is an influence between customer satisfaction variables on customer loyalty variables.

Hypothesis $4 \quad$ There is a direct influence between service quality variables on customer loyalty variables.

Hypothesis 5 There is a direct influence between promotional variables and customer loyalty variables.

\section{RESEARCH METHOD}

The scale used in this study is the Likert scale. The data that has been collected through a questionnaire, then the authors process it into quantitative form, namely by determining the answer score of the response to the statement given by the respondent, where the score is based on the provisions of number 1 , strongly disagrees up to number 5 , strongly agrees ( Sugiono, 2010). This study used a sample of 200 respondents. The research technique used in sampling is purposive sampling. The data analysis technique used in this study is to use the Analysis of Moment Structure (AMOS) to analyze the available data. Amos allow to match models for two or more groups simultaneously and summarize how well all of them fit into the chi square statistical value.

\section{RESULT AND DISCUSSION}

The results of the model testing that have been carried out show reasonably good results with the criteria of goodness for fit, which can be seen below:

Table 1. Result of Structural Model GOF Evaluation

\begin{tabular}{llll}
\hline Goodness-Of-Fit (GOF) & Cut of Value & Hasil Analisis & Evaluasi Model \\
\hline Chi-square & Diharapkan kecil & 14,865 & Fit \\
\hline Sig. Probability & $\geq 0,05$ & 0,387 & Fit \\
\hline CMIN/DF & $\leq 2,00$ & 1,062 & Fit \\
\hline
\end{tabular}




\begin{tabular}{llll}
\hline GFI & $\geq 0,90$ & 0,982 & Fit \\
\hline AGFI & $\geq 0,90$ & 0,953 & Fit \\
\hline TLI & $\geq 0,90$ & 0,994 & Fit \\
\hline CFI & $\geq 0,90$ & 0,997 & Fit \\
\hline RMSEA & $\leq 0,08$ & 0,018 & Fit \\
\hline
\end{tabular}

Referring to the results in table 1, it can be concluded that the structural model can be declared fit, and the hypothesis testing analysis can be continued. Hypothesis testing in this study uses the following coefficient outputs:

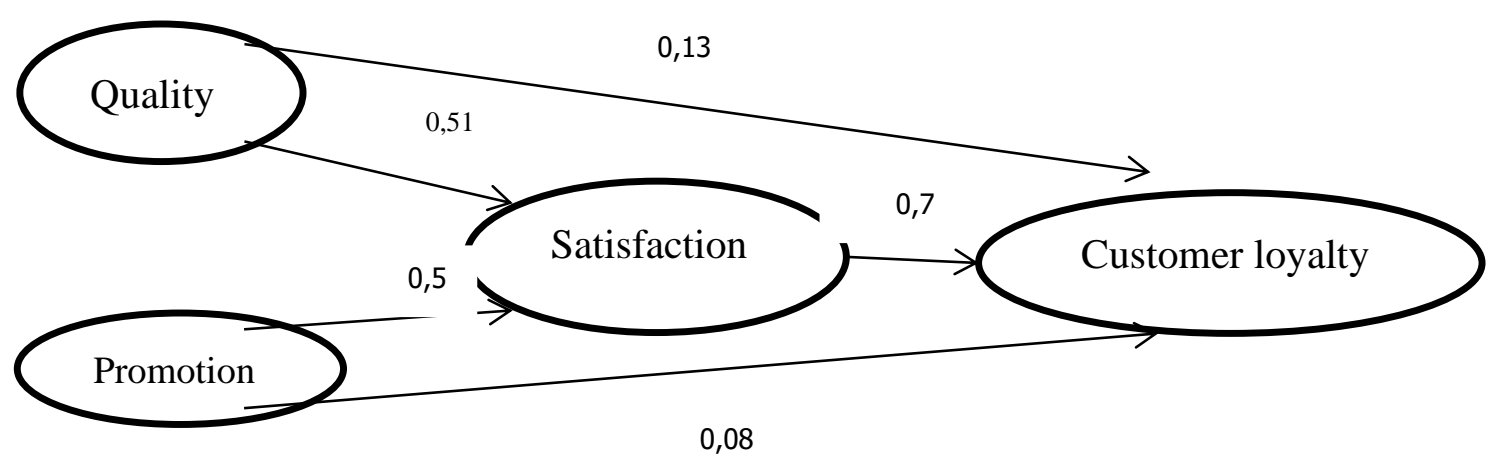

Figure 2. Regression Coefficients in Models

Service Quality has a positive and significant effect on Customer Satisfaction. This is indicated by the value of $\mathrm{CR}=3.811>1.96$ and a significance level of $0.001(* * *)$, which is below 5 percent alpha. Thus the hypothesis $\mathrm{H} 1$ is proven in this analysis. This is in line with research from Markonah (2017) and Dewa (2018), which also shows that Service Quality has a positive and significant effect on Customer Satisfaction. Therefore, it can be explained that positive service quality will encourage customer satisfaction. So that mobile payment must continue to maintain the service quality consistently to boost increased customer satisfaction. The promotion has a positive and significant effect on customer satisfaction. This is indicated by the value of $\mathrm{CR}=2.649>1.96$ and a significance level of 0.008 , which is below 5 percent alpha. Thus the $\mathrm{H} 2$ hypothesis is proven in this analysis. This is in line with research from Tjahjaningsih (2012) and Putra (2013), which also shows that promotion has a positive and significant effect on Customer Satisfaction. Therefore it can be explained that a positive promotion will create customer 
satisfaction, so that the mobile payment must increase the promotion that has been run to encourage an increase in customer satisfaction.

Customer satisfaction has a positive and significant effect on customer loyalty. This is indicated by the value of $\mathrm{CR}=2,645>1.96$ and a significance level of 0.008 , which is below 5 percent alpha. Thus the hypothesis $\mathrm{H} 1$ is proven in this analysis. This is in line with research from Ishak (2017) and Bahar (2015), which also shows that Customer Satisfaction has a positive and significant effect on Customer Loyalty. Therefore, it can be explained that positive customer satisfaction will encourage customer loyalty. So that mobile payment must continue to maintain and create customer satisfaction consistently to encourage increased customer loyalty. Service Quality has no significant effect on Customer Loyalty. This is indicated by the value of $\mathrm{CR}=0.637<1.96$ and a significance level of 0.524 , which is above 5 percent alpha. Thus the hypothesis H4 is not proven in this analysis. This shows that service quality is not strong enough to affect customer loyalty. This is in line with research conducted by Halim (2014) and Wulan (2019), which also shows that there is no significant influence between service quality variables and customer loyalty variables. However, this study's results are different from research conducted by Aziz (2017) and Ishak (2017), namely that service quality has a positive and significant effect on customer loyalty. Therefore, it is better if mobile payments look for ways to improve the quality of existing services, so that later it can build customer loyalty.

The promotion has no significant effect on customer loyalty. This is indicated by the value of $\mathrm{CR}=0.430<1.96$ and a significance level of 0.667 , which is above 5 percent alpha. Thus the hypothesis H5 is not proven in this analysis. This shows that the promotion is not strong enough to affect customer loyalty. This is in line with research conducted by Anggia et al. (2015), which also shows no significant influence between promotional variables and customer loyalty variables. However, this study's results are different from the research conducted by Aditya (2011) and Koyong et al. (2016), namely that promotion has a positive and significant effect on customer loyalty. Therefore, it is better if mobile payments look for ways how to improve existing promotions so that later it can build customer loyalty. 


\section{CONCLUSION}

Based on the results of research, discussion, and analysis that have been done previously, the conclusions that can be drawn regarding the effect of service quality and promotion on customer loyalty through customer satisfaction in making transactions using Link Aja mobile payment are as follows:

1. Service quality has a positive and significant effect on customer satisfaction in making transactions using the LinkAja mobile payment

2. Promotion has a positive and significant effect on customer satisfaction in making transactions using the LinkAja mobile payment

3. Satisfaction has a positive and significant effect on customer loyalty in making transactions using the LinkAja mobile payment

4. Service quality has no effect on customer loyalty in making transactions using the LinkAja mobile payment.

5. Promotion does not affect on customer loyalty in making transactions using Link Aja mobile payment.

Based on the conclusion above, author have suggest for management implication that LinkAja need increase the service quality and promotion to get customer satisfaction, furthermore customer satisfaction can increase customer loyalty on LinkAja.

\section{References}

Aditya, Rizqi. (2011). Analisis Pengaruh Promosi, Kualitas Jasa dan Citra Produk terhadap Loyalitas Pelanggan IM3 di Kota Semarang. Skripsi Undip.

Anggia, T, L., Kawet, L., Ogi, I. Analisis Pengaruh Strategi Promosi, Harga dan Kepuasan terhadap Loyalitas Konsumen Manado Post. Jurnal EMBA Vol. 3 No. 2; Juni 2015

Ariani, D. Wahyu. 2009. Manajemen Operasi Jasa. Yogyakarta : Graha Ilmu

Arief. (2007). Pemasaran Jasa \& Kualitas Pelayanan. Malang: Bayumedia Publishing.

Aziz (2017). Pengaruh Kualitas Pelayanan terhadap Loyalitas Nasabah "Tabungan BSM". Jurnal : UMM.

Bahar,A. Sjaharuddin, H. (2015). Pengaruh Kualitas Produk dan Kualitas Pelayanan terhadap Kepuasan Konsumen dan Minat Beli Ulang. Jurnal Organisasi dan Manajemen 2015 Vol 3 p 14 
Dewa, C. B. (2018). Pengaruh Kualitas Pelayanan dan Promosi Jasa Grabcar terhadap Kepuasan Pelanggan. Jurnal.

Halim, P., Swasto, B., Hamid, D. \& Firdaus, M. R. (2014). The Influence of Product Quality, Brand Image, and Quality of Service to Customer Trust and Implication on Customer Loyalty, European Journal of Business and Management, 6, pp. 159166.

Ishak dan Azzahroh. (2017). Pengaruh Kualitas Layanan terhadap Loyalitas Nasabah Bank Syariah dengan Kepuasan sebagai Variabel Interverning. Jurnal : UMY.

Kotler, P (2001). Manajemen Pemasaran Jilid 2 Edisi Kesebelas. Jakarta: PT. Prehallindo. Koyong, M.D., Sumayku, Sontje., Kalangi, Jhony. (2016). Pengaruh Promosi terhadap Loyalitas Nasabah di PT Bank Mandiri Kantor Cabang Dotulolong Lasut Manado. Jurnal Bisnis.

Markonah. (2017). Analisis Pengaruh Mobile Banking terhadap Kepuasan dan Loyalitas Nasabah Bank Mandiri Cabang Jakarta. Jurnal FEB Unikama, pp. 470-488.

Putra, Sulistyawati. (2013). Pengaruh Bauran Pemasaran Jasa terhadap Kepuasan dan Loyalitas Nasabah PT. Pegadaian (Persero). Jurnal Unud.

Tjahjaningsih, Endang. (2014). Pengaruh Citra dan Promosi terhadap Kepuasan Pelanggan serta Dampaknya terhadap Loyalitas Pelanggan. Skripsi.

Tjiptono, F dan Chandra, G. (2012). Pemasaran Strategik. Yogyakarta: Cv. Andi. Umar, Husain. (2003). Metode Riset Perilaku Konsumen Jasa. Jakarta: Graha Indonesia. Usmara, A. (2003). Strategi Baru Manajemen Pemasaran. Yogyakarta: Amara Books. 